\title{
Sulfide invasion in the seagrass Posidonia oceanica at Mediterranean fish farms: assessment using stable sulfur isotopes
}

\author{
Morten S. Frederiksen ${ }^{1,3,{ }^{*}}$, Marianne Holmer ${ }^{1}$, Elena Díaz-Almela ${ }^{2}$, Núrià Marba ${ }^{2}$, \\ Carlos M. Duarte ${ }^{2}$ \\ ${ }^{1}$ Institute of Biology, University of Southern Denmark, Campusvej 55, 5230 Odense M, Denmark \\ ${ }^{2}$ Grup d'Oceanografica Interdiciplinar (GOI), Institut Mediterrani d'Estudis Avancats (CSIB-UIB), Miquel Marquès 21, \\ 07190 Esporles, Illes Baelars, Spain \\ ${ }^{3}$ Present address: Greenland Institute of Natural Resources, Kivioq 2, Box 570, 3900 Nuuk, Greenland
}

\begin{abstract}
The effect of organic enrichment of sediments on the composition of stable sulfur isotopes $\left(\delta^{34} \mathrm{~S}\right)$, sulfide invasion $\left(\mathrm{F}_{\text {sulfide }}\right)$ and concentrations of total sulfur (TS) and elemental sulfur $\left(\mathrm{S}^{0}\right)$ in the seagrass Posidonia oceanica was investigated along transects from 3 Mediterranean fish farms in Spain, Italy and Greece. The $\delta^{34} \mathrm{~S}$ decreased and $\mathrm{F}_{\text {sulfide, }} \mathrm{TS}$ and $\mathrm{S}^{0}$ decreased with distance from the fish farms indicating a higher invasion of sulfide in seagrasses close to the farms. Changes in plant sulfur parameters were linked to sedimentation of organic carbon, sediment organic matter pools and sediment sulfide production (sulfate reduction rates), but relationships were not statistically significant. The most significant changes in seagrass sulfur parameters took place in the roots and rhizomes, whereas leaves showed minor or no changes along the transects and among farms. Roots had the lowest $\delta^{34} \mathrm{~S}$, indicating that sulfide entered the plants here and moved to the other plant compartments. Significant correlations between $\mathrm{S}^{0}$ and $\mathrm{F}_{\text {sulfide }}$ suggested that sulfide derivatives were accumulating inside the plant and isotopic analysis confirmed that the $\delta^{34} \mathrm{~S}$ signal of $\mathrm{S}^{0}$ extracted from the plants was similar to the $\delta^{34} \mathrm{~S}$ of sediment sulfide. The mortality of $P$. oceanica was negatively correlated to $\delta^{34} \mathrm{~S}$ in the plant, indicating higher plant mortality with increasing sulfide invasion. The usability of stable sulfur isotopes as indicators of seagrass sulfide exposure is good, except in situations with high variation in $\delta^{34} \mathrm{~S}$ of the sulfur sources, as observed at the fish farm in Spain. This variation may be adjusted for by calculating $F_{\text {sulfide }}$.
\end{abstract}

KEY WORDS: Stable sulfur isotopes $\cdot$ Seagrass $\cdot$ Sulfide $\cdot$ Fish farms $\cdot$ Posidonia oceanica

\section{INTRODUCTION}

The seagrass Posidonia oceanica is one of the most important primary producers in the Mediterranean covering between 25000 and $50000 \mathrm{~km}^{2}$ of the coastal zone (Pasqualini et al. 1998). The plant is, however, in a state of regression across the Mediterranean due to anthropogenic activities such as direct mechanical damage by trawling, construction works and eutrophication of the coastal zones (Gonzalez-Correa et al. 2005, Marba et al. 2005). Large declines of P. oceanica have also been reported in areas with marine aquaculture activities (Delgado et al. 1997, Ruiz et al. 2001, Marba et al. 2006) where release of dissolved nutrients and sedimentation of particulate organic matter from waste products change conditions in the water column and in the sediment. The released nutrients stimulate growth of phytoplankton and epiphytes, reducing the light available for the seagrasses; in addition, the epiphytes lead to increased grazing pressure on the plants (Ruiz et al. 2001). In the sediment, the degradation of organic material, mainly through aerobic 
mineralization and sulfate reduction, causes anoxic sediment conditions and elevated concentrations of sulfide (Holmer \& Kristensen 1992, Holmer \& Frederiksen 2007). Sulfide is potentially toxic to plants, affecting the function of various metallo-enzymes and ATP production (Allam \& Hollis 1972, Koch \& Erskine 2001). The combined effects of sulfide and anoxia have been shown to significantly affect seagrass growth and survival (Goodman et al. 1995) and are considered major causes of seagrass die-back events (Carlson et al. 1994, Borum et al. 2005). Further, the negative effects of sulfide are believed to be more profound in carbonate rich, iron poor sediments characteristic of the Mediterranean, with little capacity of binding and removing the toxic sulfides from the porewater (Chambers et al. 2001). Sulfide may therefore significantly influence growth and survival of $P$. oceanica in the vicinity of fish farms, but little is known about the tolerance to sulfide of this seagrass.

Seagrasses have adapted to anoxic and highly reduced sediment conditions by developing an internal system of air channels (lacunae) where oxygen can move by gas phase diffusion from the leaves to the rhizomes and roots (Roberts et al. 1984, Greve et al. 2003) enabling these tissues to maintain aerobic metabolism despite growing in anoxic sediment. Oxygen in excess of respiratory needs diffuses out of the roots, creating a sphere of oxic sediment, where sulfide and other reduced compounds are oxidized and thereby prevented from damaging the plant (Jensen et al. 2005, Frederiksen \& Glud 2006). In some cases, for example at night when photosynthesis is absent or if the oxygen concentration in the water column is low, oxygen transport to the roots is reduced and sulfide may enter the plant (Pedersen et al. 2004, Borum et al. $2005,2006)$. As for oxygen, the sulfide moves between roots, rhizomes and leaves by gas phase diffusion in the plant lacunae (Pedersen et al. 2004, Borum et al. 2005) and at some point, depending on the plant oxygen status, is exposed to oxygen. The mechanisms for sulfide reoxidation in plants are not well known, but possible oxidation products include elemental sulfur $\left(\mathrm{S}^{0}\right)$, sulfate $\left(\mathrm{SO}_{4}{ }^{2-}\right)$, thiosulfate $\left(\mathrm{S}_{2} \mathrm{O}_{3}{ }^{2-}\right)$ and others (Jørgensen \& Bak 1991). Recent studies showed an accumulation of $\mathrm{S}^{0}$ in tissues of Zostera marina exposed to sulfide suggesting $\mathrm{S}^{0}$ to be one of the important reoxidation products (Holmer et al. 2005, Frederiksen et al. 2006). Whether an uncontrolled invasion of sulfide and accumulation of sulfur also happens in Posidonia oceanica exposed to high sulfide concentrations in the sediment is not known.

Stable sulfur isotopes have previously been used to detect sulfide invasion and uptake of rooted macrophytes (Fry et al. 1982, Raven \& Scrimgeour 1997). This technique takes advantage of the different isotopic composition of the 2 main sulfur sources for the plants which are sulfate, either derived from the seawater or the sediment porewater, and sulfide in the sediment porewater (Fry et al. 1982, Raven \& Scrimgeour 1997). Sulfate reducing bacteria discriminate against the heavy ${ }^{34} \mathrm{~S}$ isotope relative to ${ }^{32} \mathrm{~S}$ and the sulfide produced ends up with a different isotopic composition $\left(\delta^{34} \mathrm{~S}-\right.$ signal) than sulfate. Sulfate generally shows remarkably constant $\delta^{34} \mathrm{~S}$ around $+21 \%$ in seawater (Rees et al. 1978) but is more variable in sediment porewater, where values up to $+60 \%$ may be found (Kaplan et al. 1963, Jørgensen 1979). The $\delta^{34} \mathrm{~S}$ of sediment sulfides varies considerably, usually in the range from $-10 \%$ o to $-20 \%$, and individual values as low as $-50 \%$ have been observed (Strauss 1997). Seagrasses invaded by sulfides are therefore expected to have a lower $\delta^{34} \mathrm{~S}$ signal than plants not subjected to sulfide invasion (Fry et al. 1982, Frederiksen 2005).

As Posidonia oceanica is one of the slowest growing seagrass species in the world and rarely reproduces sexually (Hemminga \& Duarte 2000) recovery times after disturbances are long, in the order of centuries (Duarte 1995, 2002). With an expected expansion of marine aquaculture in the Mediterranean over the coming years $\left(\sim 6 \% \mathrm{yr}^{-1}\right.$, UNEP 2002) the pressure on $P$. oceanica increases and extensive knowledge of the factors that control growth and survival of $P$. oceanica is essential. This study focuses on the effects of increased sediment sulfide concentrations in fish farm areas on the invasion and accumulation of sulfide in $P$. oceanica. The composition of stable sulfur isotopes and concentrations of total (TS) and elemental sulfur $\left(\mathrm{S}^{0}\right)$ are determined for $P$. oceanica at 3 fish farms situated in different parts of the Mediterranean (Spain, Italy and Greece). Further, the level of sulfide exposure in the sediment is assessed from measurements of sulfate reduction rates (SRR), sediment sulfur pool sizes, porewater sulfide concentrations and depth of sulfide front along transects from the fish farms. Possible relationships between the $\delta^{34} \mathrm{~S}$ signal in the plant and sulfide exposure in the sediment are investigated as well as the effects of sulfide invasion on TS and $\mathrm{S}^{0}$ concentrations in the seagrass and on seagrass mortality.

\section{MATERIALS AND METHODS}

Study sites. The 3 fish farms were located in Spain, Italy and Greece (Fig. 1). The Spanish farm was situated near the village of El Campello (SE Spain) with fish cages placed at depths between 26 and $28 \mathrm{~m}$ (Table 1). The operation began in 1997 and the annual production had been around $260 \mathrm{t} \mathrm{yr}^{-1}$. The sediment consists of fine carbonate sand and Posido- 


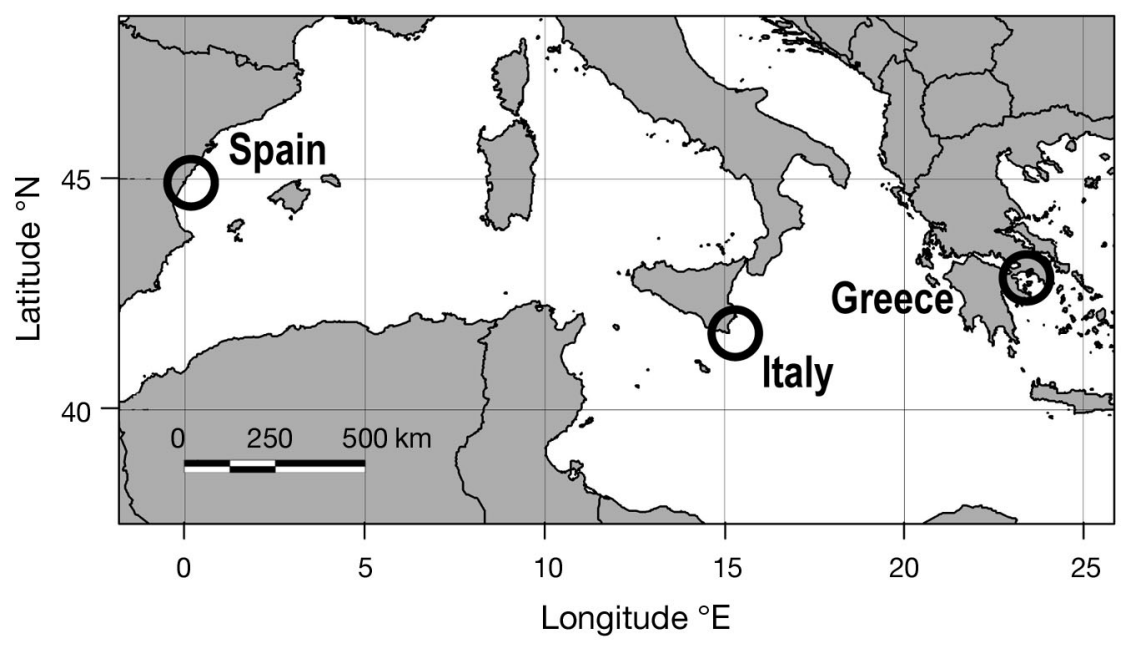

Fig. 1. The 3 study sites in Spain, Italy and Greece

study sites as described above. At each station, sediment cores and plants of Posidonia oceanica were collected by SCUBA diving and transported to the laboratory for further analysis.

Sediment analyses. The bulk sedimentation rate and sedimentation of organic carbon (and other parameters, see Holmer et al. 2007) was quantified by benthic traps deployed for $48 \mathrm{~h}$ about $50 \mathrm{~cm}$ above sediment surface. The traps consisted of $20 \mathrm{ml}$ cylindrical glass centrifugation tubes with an aspect ratio of 5 , in order to prevent resuspension. The trap material was collected on a GF/C filter and analyzed for particulate organic carbon (POC) by elemental analyzer combustion continuous flow isotope ratio mass spectrom-

nia oceanica meadows were present about $10 \mathrm{~m}$ from the cages. The farm in Italy was situated in Pachino Bay on the SE coast of Sicily at 22 to $24 \mathrm{~m}$ depth.

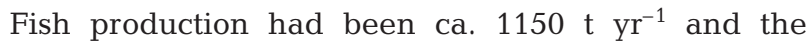
operation started in 1992. P. oceanica was present less than $5 \mathrm{~m}$ from the cages, growing in mixed carbonate sand and rock. The Greek farm was located at the south coast of Attiki between the mainland and the Island of Patroklos. The farm had been operating since 1997 with an annual fish production of

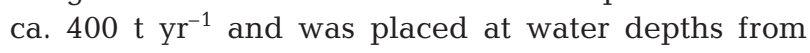
15 to $20 \mathrm{~m}$. The sediment consisted of carbonate sand with $P$. oceanica present about $15 \mathrm{~m}$ from the cages. At all farms the reared species were sea bream Sparus aurata and seabass Dicentrarchus labrax, with sharpsnout seabream Diplodus puntazzo being produced in Italy in addition to sea bream and seabass.

Sampling. Sampling was carried out during September 2002 in Italy and during June and September 2003 in Spain and Greece, respectively, corresponding to the season with maximum fish production. At each farm 3 sampling stations were placed at increasing distance from the farms down-stream in the main current direction. Stn 1 was placed close to the cages (5 to $15 \mathrm{~m}$ ), Stn 2 was 35 to $40 \mathrm{~m}$ away and Stn 3, acting as control site, was 1000 to $1200 \mathrm{~m}$ away from the farm (Table 2). The exact position of each sampling station along the transects varied slightly among the farms due to variance in the presence of seagrasses at the 3 etry (EA-C-CF-IRMS, Iso-Analytical). Prior to analysis, each sample ( 100 mg) was acidified $(2 \mathrm{ml} 10 \% \mathrm{HCl})$ for $12 \mathrm{~h}$ to remove carbonate carbon. The sediment POC contents were measured in dry sediment with a Carlo Erba elemental analyzer following Kristensen \& Andersen (1987).

Rates of sulfate reduction were measured using the core injection technique (Jørgensen 1978) where radioactive ${ }^{35} \mathrm{~S}_{-} \mathrm{SO}_{4}{ }^{2-}$ was injected into a sediment core at $1 \mathrm{~cm}$ intervals down to $10 \mathrm{~cm}$ and incubated for 2 to $4 \mathrm{~h}$ in darkness, after which the sediment was sliced in $1 \mathrm{~cm}$ intervals and preserved in $1 \mathrm{M}$ zinc acetate. The sediment was distilled according to the 2-step procedure of Fossing \& Jørgensen (1989) to obtain the acidvolatile sulfur fraction (AVS) of sulfides containing the pools of porewater sulfide and FeS and the chromium reducible sulfur (CRS) pools consisting of $\mathrm{FeS}_{2}$ and $\mathrm{S}^{0}$. Radioactivity was counted on a scintillation counter

Table 1. Characteristics of the 3 fish farms studied. DW: dry wt

\begin{tabular}{|c|c|c|c|}
\hline Characteristic & Spain & Italy & Greece \\
\hline Water depth (m) & 28 & 22 & 16 \\
\hline Sediment conditions & $\begin{array}{l}\text { Carbonate } \\
(82 \% \text { DW) }\end{array}$ & $\begin{array}{l}\text { Carbonate } \\
\text { (94\% DW) }\end{array}$ & $\begin{array}{l}\text { Carbonate } \\
(87 \% \text { DW) }\end{array}$ \\
\hline & - fine sand & - sand & - sand \\
\hline Seagrass distance from cages $(\mathrm{m})$ & $>10$ & $>5$ & $>15$ \\
\hline \multirow[t]{2}{*}{ Cultured species } & $\begin{array}{l}\text { Sea bream }{ }^{a} \\
\text { Sea bass }\end{array}$ & $\begin{array}{c}\text { Sea bream } \\
\text { Sea bass }\end{array}$ & $\begin{array}{l}\text { Sea bream } \\
\text { Sea bass }\end{array}$ \\
\hline & \multicolumn{3}{|c|}{ Sharpsnout sea bream ${ }^{c}$} \\
\hline Annual production (tonnes) & 260 & 1150 & 400 \\
\hline Feed input (tonnes) & 520 & 2749 & 640 \\
\hline $\begin{array}{l}\text { Years of operation at } \\
\text { date of sampling }\end{array}$ & 7 & 10 & 7 \\
\hline Sampling date & Sep 2002 & Sep 2003 & Jun 2003 \\
\hline
\end{tabular}


and the total SSR was calculated by integrating the rates over the $10 \mathrm{~cm}$ depth intervals and summing up the SSR of the AVS and the CRS fractions. The concentration of sulfides in the AVS and CRS pools was determined spectrophotometrically, according to the method of Cline (1969).

Direct measurements of the sulfide concentration in the sediment porewater were done in Spain and in Greece. Sediment porewater in the top $11 \mathrm{~cm}$ of sediment was extracted from intact sediment cores in $2 \mathrm{~cm}$ intervals using sippers made of closed steel syringes with $0.4 \mathrm{~mm}$ holes drilled near the end (Berg \& McGlathery 2001). Filtered samples were preserved in zinc acetate and analyzed spectrophotometrically as described above.

The depth of the sulfide front in the sediment (i.e. the sediment depth below which sulfide is present) was determined by inserting 7 or $10 \mathrm{~cm}$ long silver sticks into intact sediment cores for $12 \mathrm{~h}$. The sulfide reacts with silver to form $\mathrm{Ag}_{2} \mathrm{~S}$, which can be detected as a black precipitate on the silver sticks.

Sediment samples for analysis of the isotopic composition of sulfur $\left(\delta^{34} \mathrm{~S}\right)$ were prepared from homogenized sediment derived from the root zone $(2$ to $10 \mathrm{~cm})$. As for the SSR, the sediment was distilled according to the 2-step procedure of Fossing \& Jørgensen (1989), but

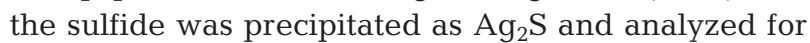
the sulfur isotopic composition at Iso-analytical, UK (Spain and Greece) or Indiana University, USA (Italy) by elemental analyzer combustion followed by isotope ratio mass spectroscopy. The stable isotopic signatures of sulfur were reported in standard delta notation (units per mille, \%o), calculated as follows:

$$
\delta^{34} \mathrm{~S}=\left[\left(\mathrm{R}_{\text {sample }} / \mathrm{R}_{\text {standard }}\right)-1\right] \times 1000
$$

where $R_{\text {sample }}={ }^{34} \mathrm{~S} /{ }^{32} \mathrm{~S}$ in the sample and $\mathrm{R}_{\text {standard }}$ is the isotopic composition of the troilite standard from the Canyon Diablo meteorite, used as a standard zero point for expression of sulfur isotopes.

Samples for measuring the $\delta^{34} \mathrm{~S}$ of sulfate in seawater and sediment porewater were prepared by centrifuging seawater or sediment $(10 \mathrm{~min}, 1500 \times g)$ followed by boiling of the supernatant under acidic conditions (3 $\mathrm{M} \mathrm{HCl}$ ) and precipitating sulfate with $\mathrm{BaCl}_{2}$ as $\mathrm{BaSO}_{4}$. Isotopic analyses of $\mathrm{BaSO}_{4}$ were made at Isoanalytical, UK

Plant analyses. The Posidonia oceanica plants were separated into leaves (2 youngest), rhizomes (horizontal with the leaf scales peeled off) and live roots and rinsed carefully with distilled water to remove salts and sediment and then freeze-dried. Homogenized tissue was packed in tin capsules together with vanadium pentoxide and analyzed for $\delta^{34} \mathrm{~S}$ and total sulfur content (TS) at Iso-analytical, UK. The amount of elemental sulfur $\left(\mathrm{S}^{0}\right)$ in the plants was determined by extracting dried plant tissue (5 to $20 \mathrm{mg}$ ) in $5 \mathrm{ml} \mathrm{HPLC}$ grade methanol for $24 \mathrm{~h}$ and measuring the concentrations of the extracted $\mathrm{S}^{0}$ by HPLC, according to Zopfi et al. (2001).

The $\delta^{34} \mathrm{~S}$ of $\mathrm{S}^{0}$ in the roots and rhizomes was determined by a modified soxhlet extraction followed by isotopic analysis (Berner 1964, Canfield et al. 1998). Briefly, between 350 to $650 \mathrm{mg}$ plant tissue was placed in methanol for $24 \mathrm{~h}$ and centrifuged $(1500 \times g, 10 \mathrm{~min})$. The supernatant was transferred to a solution with $8 \mathrm{ml}$ $6 \mathrm{M} \mathrm{HCl}, 16 \mathrm{ml} 1 \mathrm{M} \mathrm{Cr}^{2+}$ and $\mathrm{Cu}$ grains (Merck 230 mesh ASTM) and distilled by boiling for $1 \mathrm{~h}$. During distillation $\mathrm{S}^{0}$ is reduced to $\mathrm{H}_{2} \mathrm{~S}$, which is precipitated with $\mathrm{AgNO}_{3}$ as $\mathrm{Ag}_{2} \mathrm{~S}$. The $\mathrm{Ag}_{2} \mathrm{~S}$ was weighed in tin capsules together with vanadium pentoxide and analyzed for $\delta^{34} \mathrm{~S}$ as described for the plant material. This analysis was only done on roots from the Italian site and, due to the considerable amounts of plant tissue needed for the analysis, root tissue from Stns 1 \& 2 was pooled.

In order to estimate how much of the total sulfur in the plants was derived from sediment sulfide, the parameter $\mathrm{F}_{\text {sulfide }}$ was estimated using the following mixing equation:

$$
\mathrm{F}_{\text {sulfide }}=\frac{\delta^{34} \mathrm{~S}_{\text {tissue }}-\delta^{34} \mathrm{~S}_{\text {sulfate }}}{\delta^{34} \mathrm{~S}_{\text {sulfide }}-\delta^{34} \mathrm{~S}_{\text {sulfate }}} \times 100
$$

where $\delta^{34} \mathrm{~S}_{\text {tissue }}$ is the value measured in the leaf, rhizome or root, $\delta^{34} \mathrm{~S}_{\text {sulfate }}$ is the value measured in the seawater and the $\delta^{34} \mathrm{~S}_{\text {sulfide }}$ is the value measured in the AVS pool, which includes porewater sulfide potentially invading the seagrasses. At stations where data from 
AVS pools were not available, data from the nearest station were used. $F_{\text {sulfide, }}$ in contrast to direct measurements of plant $\delta^{34} \mathrm{~S}$, adjusts for the observed variation in $\delta^{34} \mathrm{~S}$ of the sulfur sources. Variable signals of sulfur sources will affect plant $\delta^{34} \mathrm{~S}$ and thus prevent direct comparisons between sites and stations, but the $\mathrm{F}_{\text {sulfide }}$ overcomes this problem (Frederiksen et al. 2006).

Statistical analyses. Data from each farm were tested for normality and homogeneity of variance. Sediment data on SRR, AVS and CRS pool, and depth of sulfide front were evaluated using 1-way ANOVA (factor: station). A 2-way ANOVA was used to evaluate sediment $\delta^{34} \mathrm{~S}$ (factors: station and pool) and plant $\delta^{34} \mathrm{~S}$, $F_{\text {sulfide, }}$ TS and $\mathrm{S}^{0}$ (factors: station and plant tissue). The ANOVA tests were followed by a post-hoc Bonferroni adjusted Fisher's LSD test. Linear regression analysis was used to test for significant relationships between plant and sediment parameters. Tests were performed at the $\mathrm{p}<0.05$ significance level and all statistical analyses were carried out in SAS ver. 8.02 (SAS Institute).

\section{RESULTS}

\section{Sediment properties}

The bulk sedimentation and sedimentation of particulate organic carbon decreased exponentially with distance from the farms, but variation was quite high and changes were not significant (see Holmer et al. 2007 for further details) (Table 2). Sediment content of particulate organic carbon (POC) also decreased exponentially with distance (see Holmer et al. 2007 for further details) (Table 2). The sediment SRR and AVS pools decreased with distance from the farms (significant for Italy [ $p<0.05$ ] Table 3 ). AVS pools in Italy were also markedly higher than the rest of the sites. The CRS pools showed no significant pattern of change with distance from the fish farms. The depth of

Table 3. Sulfate reduction rates (SRR), depth of the $\mathrm{H}_{2} \mathrm{~S}$ front (depth below which $\mathrm{H}_{2} \mathrm{~S}$ is present), $\mathrm{H}_{2} \mathrm{~S}$ concentrations (conc.), pools of acid volatile sulfur (AVS) and chromium reducible sulfur $(\mathrm{CRS}) \pm \mathrm{SE}(\mathrm{n}=3)$ in sediment of the 3 sites

\begin{tabular}{|lcccccc|}
\hline Site & Stn & $\begin{array}{c}\mathrm{SRR} \\
\left(\mathrm{mmol} \mathrm{m}^{-2} \mathrm{~d}^{-1}\right)\end{array}$ & $\begin{array}{c}\text { Depth } \mathrm{H}_{2} \mathrm{~S} \\
\text { front }(\mathrm{cm})\end{array}$ & $\begin{array}{c}\mathrm{H}_{2} \mathrm{~S} \mathrm{conc.} \\
(\mu \mathrm{M})\end{array}$ & $\begin{array}{c}\mathrm{AVS} \\
\left(\mathrm{mol} \mathrm{m}^{-2}\right)\end{array}$ & $\begin{array}{c}\text { CRS } \\
\left(\mathrm{mol} \mathrm{m}^{-2}\right)\end{array}$ \\
\hline Spain & 1 & $24.2 \pm 4.7$ & $0.3 \pm 0.2$ & $19.3 \pm 2.3$ & $0.12 \pm 0.07$ & $23.95 \pm 1.43$ \\
& 2 & $7.8 \pm 0.7$ & $0.2 \pm 0.1$ & $10.3 \pm 4.1$ & $0.13 \pm 0.03$ & $18.27 \pm 1.93$ \\
& 3 & $9.9 \pm 1.8$ & $>10.0$ & $9.1 \pm 3.9$ & $0.04 \pm 0.01$ & $15.61 \pm 3.23$ \\
Italy & 1 & $38.9 \pm 10.8$ & $0.5 \pm 0.3$ & - & $0.40 \pm 0.09$ & $12.12 \pm 0.54$ \\
& 2 & $42.0 \pm 2.7$ & $4.0 \pm 1.7$ & - & $0.58 \pm 0.42$ & $18.12 \pm 3.40$ \\
& 3 & $19.1 \pm 2.5$ & $6.2 \pm 0.8$ & - & $0.01 \pm 0.00$ & $13.07 \pm 0.41$ \\
Greece & 1 & $14.5 \pm 5.0$ & $1.1 \pm 0.6$ & $4.7 \pm 0.4$ & $0.07 \pm 0.05$ & $0.77 \pm 0.01$ \\
& 2 & $13.9 \pm 0.8$ & $5.6 \pm 1.5$ & $4.2 \pm 2.4$ & $0.04 \pm 0.01$ & $1.23 \pm 0.08$ \\
& 3 & $6.4 \pm 0.8$ & $6.9 \pm 1.9$ & $1.6 \pm 1.1$ & $0.04 \pm 0.01$ & $3.25 \pm 0.28$ \\
\hline
\end{tabular}

the sulfide front generally increased with distance from the fish farms with sulfide present almost to the sediment surface at Stn 1 compared to $>6 \mathrm{~cm}$ depth at $\mathrm{Stn}$ 3. The degree of $\mathrm{Ag}_{2} \mathrm{~S}$ precipitation varied markedly among the 3 fish farms with the most extensive precipitation in Italy. Direct measurements of the porewater concentrations of sulfide in Spain and Greece were generally low (maximum average concentrations of $19.3 \mu \mathrm{M}$ and $4.7 \mu \mathrm{M}$, respectively) with the highest concentrations at Stn 1 (not significant).

The $\delta^{34} \mathrm{~S}$ of $\operatorname{AVS}\left(\delta^{34} \mathrm{~S}_{\mathrm{AVS}}\right)$ and $\mathrm{CRS}\left(\delta^{34} \mathrm{~S}_{\mathrm{CRS}}\right)$ pools varied among the 3 study sites and also showed variation with distance from the farms (Fig. 2a). The most pronounced changes were in Greece, where $\delta^{34} \mathrm{~S}_{\mathrm{CRS}}$ decreased significantly ( $p<0.05$ ) with distance from the farm, and in Spain, where $\delta^{34} \mathrm{~S}_{\mathrm{AVS}}$ increased noticeably, however not significantly, from Stn 2 to Stn 1 . The $\delta^{34} \mathrm{~S}_{\mathrm{AVS}}$ sulfur pool was on average $9.7 \%$ higher than $\delta^{34} \mathrm{~S}_{\mathrm{CRS}}$, but in Spain differences as large as $24 \%$ o were observed. Due to the small amounts of sulfides in the AVS pool, it was not possible to obtain enough material for isotopic analysis of this pool at the control stations (Stn 3).

The $\delta^{34} \mathrm{~S}$ of sulfate in seawater was nearly constant across the Mediterranean, ranging from $+20.0 \%$ in Italy to $+21.2 \%$ in Spain (Table 4 ). The $\delta^{34} \mathrm{~S}$ of porewater sulfate was measured once at each station along the transects and as no apparent change was observed with distance from the farms the results from each transect were pooled to obtain 3 replicates from each farm (Table 4). There was no significant variation among the sites and average values ranged from $+19.5 \%$ in Italy to $+21.9 \%$ in Spain.

\section{Plant properties}

The $\delta^{34} \mathrm{~S}$ signal was significantly $(\mathrm{p}<0.05)$ lower in roots and rhizomes of Posidonia oceanica compared to leaves (Fig. 2b). Values ranged from +6.1 to $+15.3 \%$ o in roots and from +10.8 to $+16.5 \%$ in rhizomes compared to +20.7 to $22.8 \%$ in leaves. The $\delta^{34} \mathrm{~S}$ of roots increased with distance from the farms ( $\mathrm{p}<0.05$ for Spain and Italy). The rhizomes showed a similar trend in Italy and Greece, though this is not statistically significant. Leaf $\delta^{34} \mathrm{~S}$ was similar at the 3 sites and did not change with distance from the farms.

The calculations of $F_{\text {sulfide }}$ showed that roots and rhizomes had derived a significantly ( $p<0.05)$ higher proportion of the sulfur from sediment sulfide (13 to $41 \%$ and 9 to $30 \%$, 

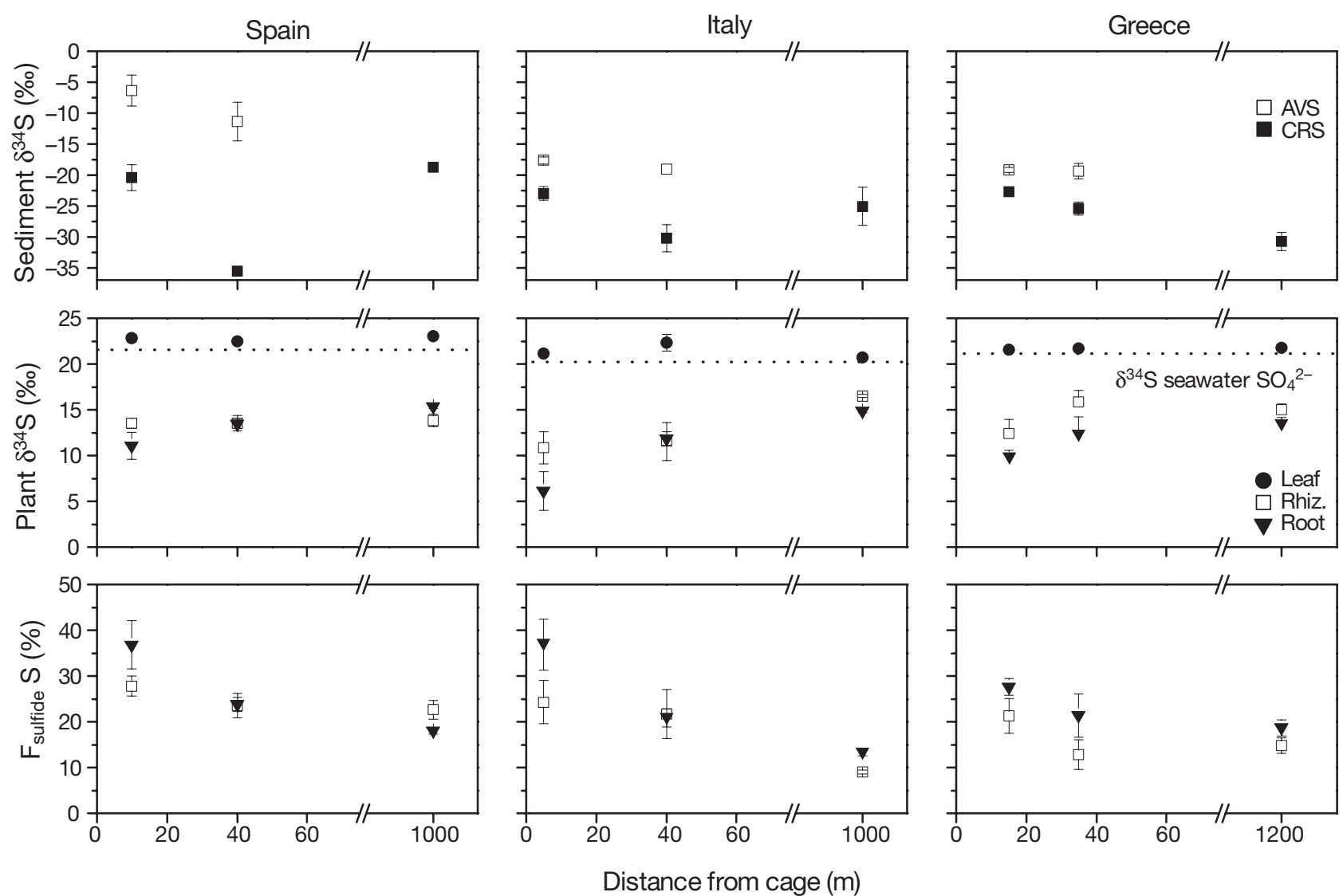

Fig. 2. Isotopic composition of sulfur (sediment and seagrass) and percent sulfide (seagrass) as a function of distance from cage. (Upper panels) $\delta^{34} \mathrm{~S}$ in sediment acid volatile sulfur (AVS) and chromium reducible sulfur (CRS) pools. $\delta^{34} \mathrm{~S}$ values are not available for AVS pools at Stn 3 (1000 to $1200 \mathrm{~m}$ from cage), due to low amounts of sulfides in samples. (Middle panels) $\delta^{34} \mathrm{~S}$ in leaves, rhizomes (Rhiz.) and roots of Posidonia oceanica at the 3 fish farm localities. (Lower panels) Fraction of total sulfur in leaves, rhizomes and roots derived from sediment sulfide $\left(\mathrm{F}_{\text {sulfide }}\right)$. Note that leaves derived none of their sulfur from sediment sulfide. Error bars: SE $(\mathrm{n}=3)$

respectively) compared to leaves, where none of the sulfur was derived from sediment sulfide (Fig 2c). The $F_{\text {sulfide }}$ decreased with distance from the farms in roots and rhizomes, significant $(\mathrm{p}<0.05)$ between Stns 1 and 3 in Spain (roots), Greece (roots and rhizomes) and Italy (roots).

TS concentrations in the tissue showed different patterns of change at the different locations (Table 5). In Spain TS decreased significantly $(p<0.05)$ with distance from the farm in rhizomes and roots, but not in leaves. The same trend was observed in roots and rhizomes from Greece and in leaves and roots from Italy, but changes were less pronounced and not significant.

The concentrations of $\mathrm{S}^{0}$ were highest in roots (range: 0.3 to $2.2 \mu \mathrm{mol} \mathrm{gDW}{ }^{-1}$ ), followed by rhizomes (range from below the detection limit of $0.1 \mu \mathrm{mol}$ $\mathrm{gDW}^{-1}$ to $0.3 \mu \mathrm{mol} \mathrm{gDW}^{-1}$ ) and leaves (below detection limit, Table 5). $\mathrm{S}^{0}$ decreased significantly in roots with dis- tance from the farms in Spain and Italy $(\mathrm{p}<0.05)$ and to some extent in Greece. Elemental sulfur contributed little $(<2 \%)$ to the total sulfur concentration in the Posidonia oceanica plants.

The $\delta^{34} \mathrm{~S}$ of $\mathrm{S}^{0}$ extracted from the plant roots from Italy was markedly lower than $\delta^{34} \mathrm{~S}$ of the total sulfur in the plants and very close to the $\delta^{34} \mathrm{~S}$ of sediment sulfide (Table 6). The difference was not tested statistically due to lack of replicates.

Possible relationships between $\delta^{34} \mathrm{~S}$, TS and $\mathrm{S}^{0}$ in Posidonia oceanica were explored by regression analysis (Fig. 3). The $\delta^{34} \mathrm{~S}$ of roots and rhizomes decreased

Table $4 . \delta^{34} \mathrm{~S}$ of sulfate in seawater and in bulk porewater of sediment $\pm \mathrm{SE}$ $(\mathrm{n}=3)$. Porewater $\delta^{34} \mathrm{~S}$ is average of 3 measurements along the transect (1 at each station)

\begin{tabular}{|lccr|}
\hline & Spain & Italy & \multicolumn{1}{c|}{ Greece } \\
\hline$\delta^{34}$ S seawater $(\%)$ & $21.19 \pm 0.05$ & $20.00 \pm 0.03$ & $20.97 \pm 0.02$ \\
$\delta^{34}$ S porewater $(\%)$ & $21.88 \pm 0.17$ & $19.49 \pm 0.41$ & $21.2 \pm 0.13$ \\
\hline
\end{tabular}


Table 5. Posidonia oceanica. Total sulfur $(\mathrm{TS})$ and $\mathrm{S}^{0}$ concentrations $\pm \mathrm{SE}(\mathrm{n}=3)$ in leaves, rhizomes and roots at the 3 sites. Concentrations of $\mathrm{S}^{0}$ were below detection limit $(\mathrm{bd})\left(<0.1 \mu \mathrm{mol} \mathrm{gDW}^{-1}\right)$ in leaves

\begin{tabular}{|c|c|c|c|c|c|c|c|}
\hline \multirow[t]{2}{*}{ Site } & \multirow[t]{2}{*}{ Stn } & \multicolumn{3}{|c|}{$-\mathrm{TS}\left(\mu \mathrm{mol} \mathrm{g} \mathrm{DW^{-1 } )}\right.$} & \multicolumn{3}{|c|}{$\longrightarrow \mathrm{S}^{0}\left(\mu \mathrm{mol} \mathrm{g} \mathrm{DW} \mathrm{DW}^{-1}\right)$} \\
\hline & & Leaf & Rhizome & Root & Leaf & Rhizome & Root \\
\hline \multirow{3}{*}{ Spain } & 1 & $367.0 \pm 1.0$ & $226.7 \pm 24.5$ & $246.4 \pm 12.6$ & $\mathrm{bd}$ & $0.17 \pm 0.09$ & $2.17 \pm 0.67$ \\
\hline & 2 & $376.4 \pm 6.8$ & $204.8 \pm 21.6$ & $214.2 \pm 5.5$ & $\mathrm{bd}$ & $0.20 \pm 0.19$ & $1.81 \pm 0.33$ \\
\hline & 3 & $346.2 \pm 47.7$ & $187.1 \pm 31.2$ & $176.8 \pm 12.0$ & bd & bd & $0.86 \pm 0.14$ \\
\hline \multirow[t]{3}{*}{ Italy } & 1 & $201.7 \pm 6.3$ & $184.0 \pm 18.1$ & $206.6 \pm 18.5$ & $\mathrm{bd}$ & $0.11 \pm 0.07$ & $2.20 \pm 0.66$ \\
\hline & 2 & $187.1 \pm 6.5$ & $161.2 \pm 20.9$ & $150.8 \pm 4.5$ & $\mathrm{bd}$ & $0.33 \pm 0.21$ & $1.21 \pm 0.32$ \\
\hline & 3 & $150.8 \pm 5.5$ & $166.4 \pm 21.5$ & $206.9 \pm 15.0$ & $\mathrm{bd}$ & bd & $0.34 \pm 0.06$ \\
\hline \multirow[t]{3}{*}{ Greece } & 1 & $252.7 \pm 9.4$ & $221.5 \pm 21.9$ & $260.8 \pm 46.1$ & $\mathrm{bd}$ & $\mathrm{bd}$ & $0.87 \pm 0.08$ \\
\hline & 2 & $280.7 \pm 6.5$ & $231.2 \pm 37.3$ & $218.3 \pm 29.5$ & $\mathrm{bd}$ & $\mathrm{bd}$ & $0.49 \pm 0.19$ \\
\hline & 3 & $261.5 \pm 22.3$ & $170.5 \pm 15.1$ & $248.9 \pm 17.6$ & $\mathrm{bd}$ & $0.14 \pm 0.09$ & $0.43 \pm 0.25$ \\
\hline
\end{tabular}

Table 6. Posidonia oceanica. $\delta^{34} \mathrm{~S}$ of $\mathrm{S}^{0}$ and total plant sulfur (TS) sampled in Italy. Due to high amounts of plant material required for analysis, reported values are based on single measurements and data are pooled samples from Stns 1 and 2

\begin{tabular}{|lccc|}
\hline Tissue & Site & $\delta^{34} \mathrm{~S}-\mathrm{S}^{0}(\%)$ & $\delta^{34} \mathrm{~S}-\mathrm{TS}(\%)$ \\
\hline Root & Italy & -13.4 & 9.0 \\
\hline
\end{tabular}
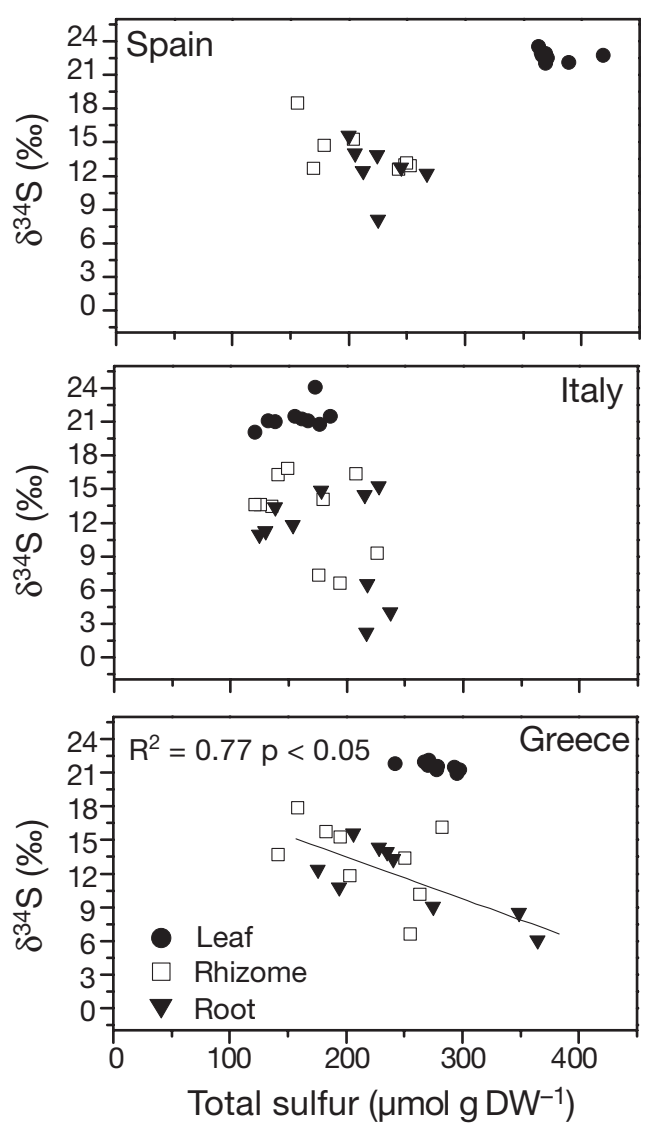

Fig. 3. Posidonia oceanica. $\delta^{34} \mathrm{~S}$ in leaves, rhizomes and roots as a function of total sulfur concentration. The relationship was only significant for roots from Greece

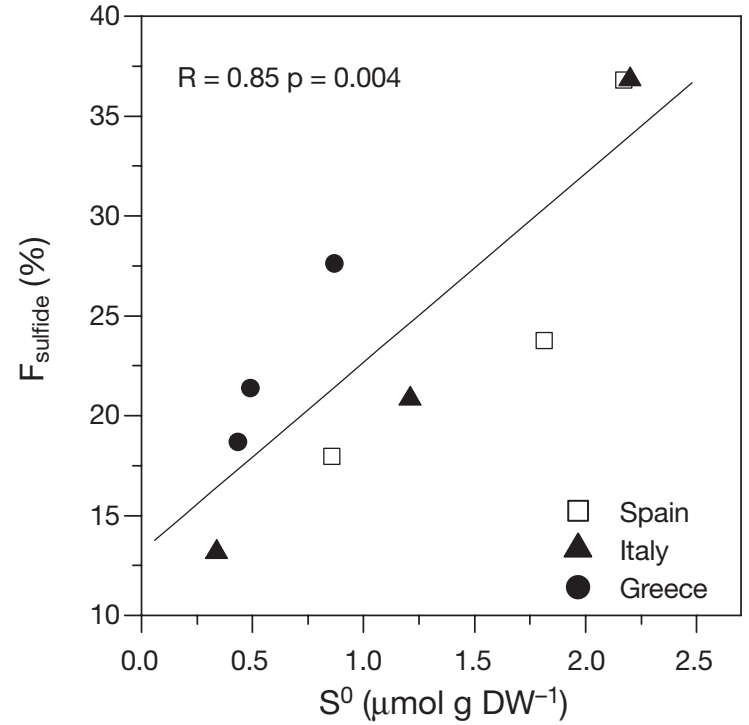

Fig. 4. Posidonia oceanica. $\mathrm{F}_{\text {sulfide }}$ in roots as a function of $\mathrm{S}^{0}$ (elemental sulfur) concentration

with increasing TS concentrations on several farms, but regressions pooling the data from all sites were not significant ( $p>0.05$, data not shown). Analyzing the farms separately showed a significant relationship in roots from Greece $\left(R^{2}=0.77, p<0.05\right.$, Fig. 3). The $\delta^{34} S$ in leaves remained constant with increasing TS concentration at all sites. The $\delta^{34} \mathrm{~S}$ showed better correlations with the $\mathrm{S}^{0}$ concentrations in the plants and regressions were strongest using the adjusted $\delta^{34} \mathrm{~S}$

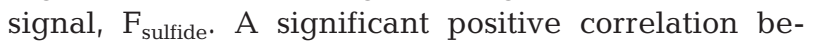
tween $\mathrm{F}_{\text {sulfide }}$ and $\mathrm{S}^{0}$ was found in roots (Fig. 4).

Relationships between plant indicators of sulfide invasion $\left(\delta^{34} \mathrm{~S}\right.$ and $\left.\mathrm{F}_{\text {sulfide }}\right)$ and environmental variables (sedimentation of $\mathrm{C}$, sediment POC content, SRR, depth of sulfide front) were explored to identify possible drivers of sulfide invasion in seagrasses. Correlations using $F_{\text {sulfide }}$ (Fig. 5) were stronger compared to those using $\delta^{34} \mathrm{~S}$ (data not shown) for all 4 environmental variables. 

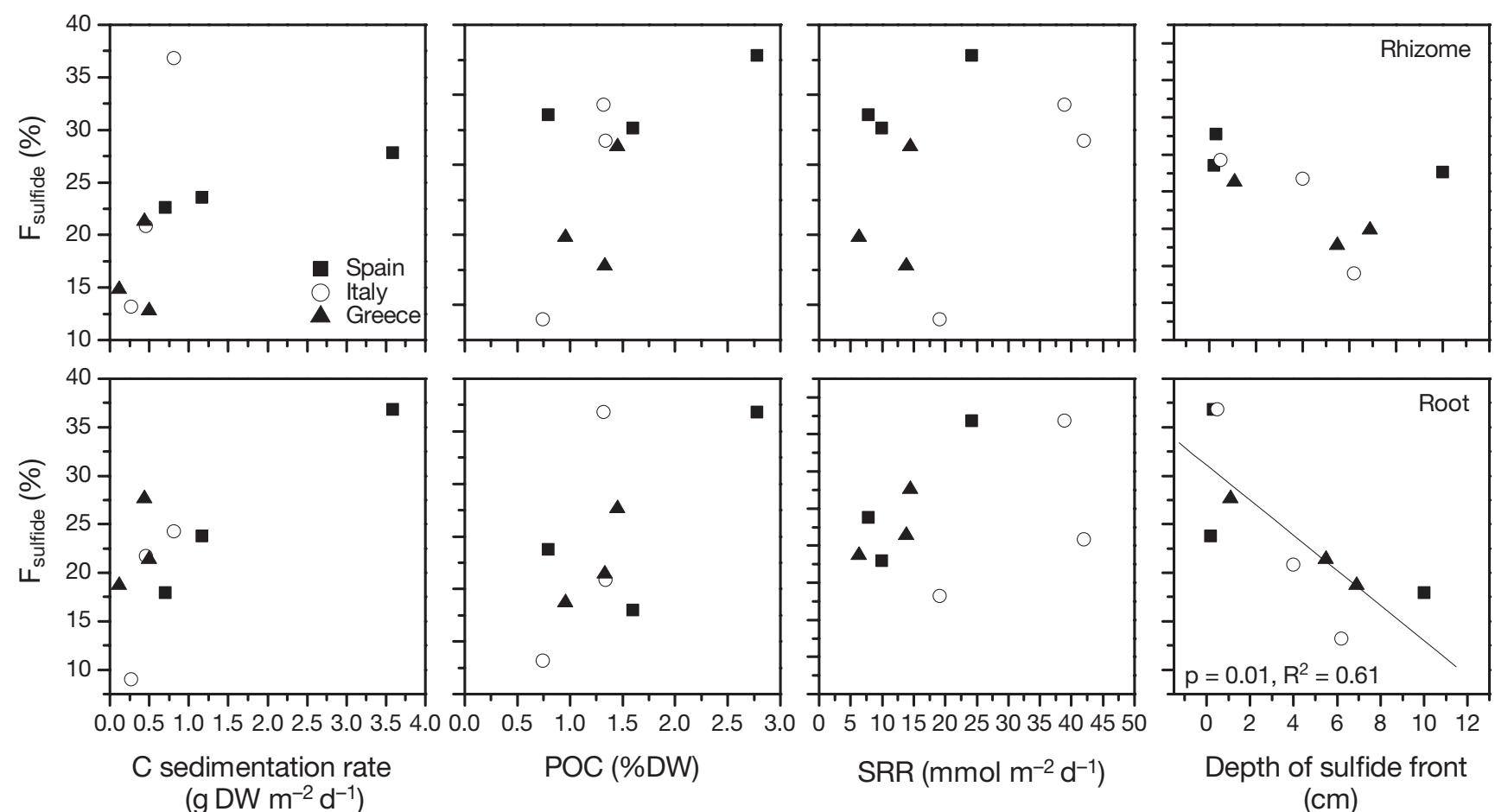

Fig. 5. Posidonia oceanica. $\mathrm{F}_{\text {sulfide }}$ in rhizomes (upper panels) and roots (lower panels) as a function of $\mathrm{C}$ sedimentation rate, sediment POC, sediment SRR and depth of sulfide front. Line indicates statistically significant trend $(p<0.05)$

\section{DISCUSSION}

\section{$\delta^{34}$ S of Posidonia oceanica}

The $\delta^{34} \mathrm{~S}$ of Posidonia oceanica was of similar range at the 3 study sites, and there was always a clear differentiation in $\delta^{34} \mathrm{~S}$ between tissues. Leaf $\delta^{34} \mathrm{~S}$ was close to $\delta^{34} \mathrm{~S}$ of seawater sulfate, whereas $\delta^{34} \mathrm{~S}$ of roots and rhizomes was significantly lower and closer to $\delta^{34} \mathrm{~S}$ of the sediment sulfides. The decrease in the $\delta^{34} \mathrm{~S}$ signal from the leaves to the roots indicates that sulfide entered the plant via the roots and moved from here to the other tissues, probably by gas phase diffusion in the lacunae, as demonstrated for Zostera marina and Thalassia testudinum (Pedersen et al. 2004, Borum et al. 2006).

Very little is known about the fate of sulfide when inside the seagrasses. The inverse relationship between the $\delta^{34} \mathrm{~S}$ and TS concentrations of roots and rhizomes in Spain and Greece suggested that the sulfide or derivatives from sulfide accumulated in the plants. The same relationship has been found in leaves, roots and rhizomes of Zostera marina (Frederiksen et al. 2006) and is likely to be a common phenomenon in seagrasses (Frederiksen 2005). Sulfide may undergo various transformations inside the plant, and the significant relationship between $\mathrm{F}_{\text {sulfide }}$ and $\mathrm{S}^{0}$ concentrations in the roots at the 3 farms suggests that sulfide is oxidized to $\mathrm{S}^{0}$ (Fig. 4). This is supported by the fact that the $\delta^{34} \mathrm{~S}$ of $\mathrm{S}^{0}$ extracted from the roots was very negative and close to the $\delta^{34} \mathrm{~S}$ of sediment sulfide (Table 6), which has also been demonstrated for Posidonia ocenica and for $Z$. marina in experimental studies (Frederiksen 2005). The oxidation process is most likely to occur in the plant lacunae, where gaseous oxygen is transported from the leaves to the below ground organs. The $\mathrm{S}^{0}$ concentrations in $P$. oceanica, however, constituted $<2 \%$ of the TS pool, whereas calculations of $\mathrm{F}_{\text {sulfide }}$ showed that 9 to $30 \%$ and 13 to $41 \%$ of the TS in rhizomes and roots, respectively, originated from sulfide. $\mathrm{S}^{0}$ therefore could not account for all sulfide-derived sulfur in the plants. This could either be attributed to a low efficiency of the $\mathrm{S}^{0}$ extraction method or that the sulfide was oxidized to other compounds such as sulfate, which is an important storage compound for excess sulfur in higher plants (Rennenberg 1984). Furthermore, sulfide could potentially be incorporated into various organic compounds, such as sulfur-containing amino acids and coenzymes. (Rennenberg 1984); however, to our knowledge this has not been demonstrated in seagrasses and requires further study.

Interestingly, the $\delta^{34} \mathrm{~S}$ of leaves, in contrast to roots and rhizomes, was remarkably close to $\delta^{34} \mathrm{~S}$ of seawater sulfate (ca. $20 \%$ ) and showed no change with increasing TS concentrations and no accumulation 
of $\mathrm{S}^{0}$. This suggests that leaves of Posidonia oceanica were not affected by sulfide, which is in contrast to Zostera marina, where $\delta^{34} \mathrm{~S}$ in leaves can be as low as $-11 \%$ (Frederiksen et al. 2006). We speculate that the reason for this difference may be related to morphological differences between the species. $P$. oceanica has both vertical and horizontal rhizomes, which is not the case for $Z$. marina, and this increases the diffusion distance from roots to rhizomes. Furthermore, variation in the development of lacunal tissue among species may influence the diffusion of sulfide between the plant organs. Microscopical inspections of rhizome transverse sections by Frederiksen (2005) showed indications of less lacunal tissue in $P$. ocenica compared to $Z$. marina, but the study did not allow for direct quantification of the lacunal extent.

\section{Effects of fish farming activities on sulfide invasion in Posidonia oceanica}

Fish farming activities at the 3 sites affected the sedimentation of organic material in the sediment, as reported in Holmer et al. (2007). They found, by including more stations along and perpendicular to the main transects, an exponential decrease in sedimentation with distance from the farms. The sedimentation of POC was 3 to $5 \times$ higher and bulk sedimentation 1.3 to $2.9 \times$ higher at Stn 1 compared to the control stations, whereas sedimentation at control stations was generally in the same range as in other Posidonia oceanica beds in these regions of the Mediterranean (Holmer et al. 2007), suggesting that they were little influenced by farming activities. Accordingly, the stable isotope signal $\left(\delta^{13} \mathrm{C}\right.$ and $\left.\delta^{15} \mathrm{~N}\right)$ of trap material was generally close to the values of feed pellets near the farm and different from control stations (Holmer et al. 2007). We cannot exclude that other organic pollution sources contributed to the sedimentation of organic matter along transects, as villages were present within a few kilometers from the farms, and the control stations therefore may not represent true pristine conditions. However, the observed sedimentation patterns at the farms strongly suggest that the fish farms were the main contributors of organic material to the sediment.

Sedimentation patterns varied among the 3 farms, with the highest sedimentation rates in Spain and the lowest rates in Greece. This difference is due to a combination of factors, such as the hydrodynamic regime, the water depth, food consumption, food conversion ratio and presence of wild fish (Sara et al. 2004), which all varied among the farms (Holmer et al. 2007). The direct quantification of organic matter deposition at the sediment surface by benthic sediment traps integrates these factors and thus provided the required information for evaluating benthic impacts of the farms. The sedimentation of fish farm effluents increased the organic matter content of the sediment, which stimulated benthic mineralization processes; this is indicated by the increase in SSR and sulfide concentrations and the decrease in the depth sulfide front at Stns 1 and 2 compared to control sites. These processes consume oxygen and produce sulfide, which are controlling factors of sulfide invasion in seagrasses (Pedersen et al. 2004), and the potential for sulfide invasion therefore increased near the farms.

The seagrass $\delta^{34} \mathrm{~S}$ generally increased and $\mathrm{F}_{\text {sulfide, }}$ TS and $\mathrm{S}^{0}$ concentrations decreased in roots and rhizomes of Posidonia oceanica with distance from the farms in Italy and Spain, and to a lesser extent in Greece, indicating that sulfide invasion was indeed higher in seagrasses close to the farms compared to control sites. The positive relationships between $\mathrm{F}_{\text {sulfide }}$ and the sedimentation of organic carbon, sediment POC content, the depth of the sulfide front and the sediment SSR support this. The correlations, however, were only significant between $\mathrm{F}_{\text {sulfide }}$ and the depth of the sulfide front (Fig. 5), but the results strongly suggest that the sedimentation of organic carbon and its derived effects on sediment biogeochemical conditions were important factors controlling sulfide invasion at the study sites.

Sulfide invasion in Posidonia oceanica varied at the 3 farms and was highest at farms with the highest sedimentation rates and sediment content of POC (Spain and Italy). Sediment biogeochemical conditions thus seemed an important explanatory factor for the observed variation in sulfide invasion between the 3 study sites. However, other factors with important influence on sulfide invasion also varied among the farms. The water depth ranged from $16 \mathrm{~m}$ in Greece to $28 \mathrm{~m}$ in Spain and light climates were therefore different. Light affects the internal oxygen status of the plants by controlling leaf photosynthesis, which in turn influences the plants ability to transport oxygen to below ground organs and maintain the oxidized sphere around the roots protecting the plant against sulfide invasion (Frederiksen \& Glud 2006). The exponential decrease in light with depth means that seagrasses at the shallow farm in Greece had better possibilities to avoid sulfide invasion compared to seagrasses at the farms in Italy and Spain, and sulfide invasion was indeed less in Greece. Interestingly, light attenuation coefficients did not change with distance from the farms ( $M$. Tsapakis pers. comm.), suggesting that the fish farm effluents did not influence light penetration in the water column along the transects. Light therefore 
cannot explain the observed changes in sulfide invasion with distance from the farms.

The shoot density increased and plant mortality decreased with distance from all 3 farms (E. DiazAlmela et al. unpubl.) indicating that Posidonia oceanica survival was affected by the farming activities. Linear regression analysis relating seagrass mortality to $\mathrm{F}_{\text {sulfide }}$ in the roots and rhizomes showed relatively strong negative relationships in Spain and Italy (Table 7), indicating that plant mortality was related to increased sulfide invasion. This is consistent with high sulfide exposure in the sediment at these sites and the strongest indications of sulfide invasion in the plants were found here. It has previously been suggested that the combined effects of plant anoxia and sulfide invasion may promote seagrass declines in organic enriched sediments (Carlson et al. 1994, Terrados et al. 1999, Duarte 2002), and the present study shows that these factors are most likely also to influence declines of $P$. oceanica.

In Greece, where sulfide exposure in the sediment was low and indications of sulfide invasion in the seagrasses were weak, mortality also decreased significantly with distance from the farm, not due to sulfide invasion (no significant regression), but probably due to increased herbivore pressure by grazing of sea urchins (M. Perez pers. comm.).

\section{Methodological considerations and constraints of the study}

Variation in $\delta^{34} \mathrm{~S}$ of the sulfur sources in water and sediments affects the usability of $\delta^{34} \mathrm{~S}$ as a direct indicator of sulfide invasion in seagrasses, because it introduces changes in plant $\delta^{34} \mathrm{~S}$ with no relation to sulfide invasion. To be able to compare plant $\delta^{34} \mathrm{~S}$ directly at the 3 study sites, the $\delta^{34} \mathrm{~S}$ of the sulfide and sulfate entering the plants should ideally be constant. The $\delta^{34} \mathrm{~S}$ of seawater sulfate could be considered

Table 7. Summary of linear regression statistics between $\mathrm{F}_{\text {sulfide }}$ in rhizomes and roots (explanantory) and plant mortality $\left(\mathrm{yr}^{-1}\right.$, dependent factor). For the regressions, replicate values of mortality at each station along the transect were plotted against an average value of $F_{\text {sulfide }}$ resulting in a total $\mathrm{n}=9$

\begin{tabular}{|lccc|}
\hline Site & Tissue & $\mathrm{R}^{2}$ & $\mathrm{p}$ \\
\hline Spain & Rhizome & 0.43 & 0.05 \\
& Root & 0.48 & 0.04 \\
Italy & Rhizome & 0.31 & 0.12 \\
& Root & 0.57 & 0.02 \\
Greece & Rhizome & 0.01 & 0.79 \\
& Root & 0.02 & 0.62 \\
\hline
\end{tabular}

constant across the Mediterranean and was close to the general mean of $+21 \%$ found in the world's oceans (Rees et al. 1978). The data available for porewater sulfate indicated that the $\delta^{34} \mathrm{~S}$ was close to seawater sulfate and rather constant. This assumption seems reasonable, as sulfate concentrations changed very little with sediment depth ( $<2 \mathrm{mM}$, results not shown), suggesting a high exchange of sulfate across the sediment/water interface or limited sulfate consumption by the sulfate reducing bacteria. In contrast, the $\delta^{34} \mathrm{~S}$ of sediment sulfides was more variable, especially in Spain, where $\delta^{34} \mathrm{~S}$ of the AVS pool was more positive compared to the other sites and increased moderately towards the farm. This variation may have affected $\delta^{34} \mathrm{~S}$ of the seagrasses and, in order to adjust for the variation, the $\mathrm{F}_{\text {sulfide }}$ was derived using $\delta^{34} \mathrm{~S}$ from seawater sulfate and $\delta^{34} \mathrm{~S}_{\mathrm{AVS}}$ in the sediment, under the assumption that these values represented the $\delta^{34} \mathrm{~S}$ of sulfur sources (sulfate and porewater sulfide) entering the plants (Frederiksen et al. 2006).

The observed changes in $\mathrm{F}_{\text {sulfide, }} \delta^{34} \mathrm{~S}$, TS and $\mathrm{S}^{0}$ do not necessarily reflect an invasion of sulfide, but could be an artifact of precipitation of sulfide and oxidized sulfur compounds on the outer surfaces of the plant (Fry et al. 1982). The plants were, however, thoroughly rinsed before analysis, and a test of the washing procedure on Zostera marina showed no significant precipitation on the outer surfaces, and the washing procedure removed the precipitates (Holmer et al. 2005, Frederiksen et al. 2006). The longer life span of Posidonia oceanica, however, allows more time for precipitates to accumulate, but the fact that changes also occurred in the rhizomes, where the leaf scales were peeled off and very little surface tissue remained, strongly suggests that changes were attributed to processes in the interior parts of the plants. Furthermore, the plants growing closest to the farms had increased amounts of free amino acids and reduced amounts of non-structural carbohydrates in the roots and rhizomes (Pérez et al. 2007), which are strong indicators of plant anaerobic metabolism (Pregnall et al. 1984, Smith et al. 1988). The roots were therefore at times anoxic, and conditions for sulfide invasion were present (Pedersen et al. 2004). It has also been argued that changes in $\delta^{34} \mathrm{~S}$ could result from the uptake of sulfate with low $\delta^{34} \mathrm{~S}$ derived from the oxidation of sulfides in the rhizosphere (Trust \& Fry 1992). This is not supported in the present study, as $\delta^{34} \mathrm{~S}$ of sulfate in the porewater was greater than $+21 \%$, and the more or less constant sulfate concentrations measured in the rhizosphere sediment indicated that the sulfate pool was constantly renewed by exchange via the sediment water interface counteracting differences in $\delta^{34} \mathrm{~S}$ of sulfate in the sediment and the overlying water. 


\section{CONCLUSIONS}

The composition of stable sulfur isotopes in plant tissues combined with information on $\mathrm{S}^{0}$ and TS concentrations were consistent indicators of sulfide invasion in Posidonia oceanica and the most significant changes occurred in roots. There was generally a strong correlation between $\delta^{34} \mathrm{~S}$ and the concentrations of $\mathrm{S}^{0}$ and to a lesser extent with TS in the plants. The usability of the $\delta^{34} \mathrm{~S}$ signal in plants as an indication of sulfide invasion is reduced if $\delta^{34} \mathrm{~S}$ of the sulfur sources vary as observed in Spain. To be able to successfully interpret results and make direct comparisons between sites therefore requires adjustments for the variation in $\delta^{34} \mathrm{~S}$ of the sulfur sources. This can be done by calculating $\mathrm{F}_{\text {sulfide }}$ as a supplement to plant $\delta^{34} \mathrm{~S}$. Fish farming activities affect sulfide invasion in $P$. oceanica, but the extent varies significantly among farms. Important controlling factors are the sedimentation rate of organic material and sediment biogeochemical conditions. Plant mortality was highest at study sites with strong indications of sulfide invasion.

Acknowledgements. We thank J. Fong at Indiana University, USA, for conducting the isotopic analyses of sediment sulfides from the farms at Cyprus and Sicily. This work was funded by MedVeg (EU contract no. Q5RS-2001-02456) and Danish Research Council grant no. 212-05-0408 and we are grateful to all MedVeg partners.

\section{LITERATURE CITED}

Allam AI, Hollis JP (1972) Sulfide inhibition of oxidases in rice roots. Phytopathology 62:634

Berg P, McGlathery KJ (2001) A high-resolution pore water sampler for sandy sediments. Limnol Oceanogr 46: 203-210

Berner RA (1964) Distribution and diagenesis of sulfur in some sediments from the Gulf of California. Mar Geol 1: $117-140$

Borum J, Pedersen O, Greve TM, Frankovich TA, Zieman JC, Fourqurean JW, Madden CJ (2005) The potential role of plant oxygen and sulphide dynamics in die-off events of the tropical seagrass, Thalassia testudinum. J Ecol 93: 148-158

Borum J, Sand-Jensen K, Binzer T, Pedersen O, Greve TM (2006) Oxygen movement in seagrasses. In: Larkum EWD, Orth RJ, Duarte CM (eds) Seagrass biology. Kluwer Academic Publishers, Dordrecht, p 255-270

Canfield DE, Boudreau BP, Mucci A, Gundersen JK (1998) The early diagenetic formation of organic sulfur in the sediments of Mangrove Lake, Bermuda. Geochim Cosmochim Acta 62:767-781

Carlson PR, Yarbro LA, Barber TX (1994) Relationship of sediment sulfide to mortality of Thalassia-testudinum in Florida Bay. Bull Mar Sci 54:733-746

Chambers RA, Fourqurean JW, Macko SA, Hoppenot R (2001) Biogeochemical effects of iron availability on primary producers in a shallow marine carbonate environment. Limnol Oceanogr 46:1278-1286
Cline JD (1969) Spectrophotometric determination of hydrogen sulfide in natural waters. Limnol Oceanogr 14:454-458

Delgado O, Grau A, Pou S, Riera F, Massuti C, Zabala M, Ballesteros E (1997) Seagrass regression caused by fish cultures in Fornells Bay (Menorca, Western Mediterranean). Oceanol Acta 20:557-563

Duarte CM (1995) Submerged aquatic vegetation in relation to different nutrient regimes. Ophelia 41:87-112

Duarte CM (2002) The future of seagrass meadows. Environ Conserv 29:192-206

Fossing H, Jørgensen BB (1989) Measurement of bacterial sulfate reduction in sediments - evaluation of a singlestep chromium reduction method. Biogeochemistry 8: 205-222

Frederiksen M (2005) Seagrass response to organic loading of meadows caused by fish farming or eutrophication. PhD Dissertation, University of Southern Denmark, Odense

Frederiksen MS, Glud RN (2006) Oxygen dynamics in the rhizosphere of Zostera marina: A 2-dimensional planar optode study. Limnol Oceanogr 51:1072-1083

Frederiksen MS, Holmer M, Borum J, Kennedy H (2006) Temporal and spatial variation of sulfide invasion in eelgrass (Zostera marina) as reflected by its sulfur isotopic composition. Limnol Oceanogr 51:2308-2318

Fry B, Scalan RS, Winters JK, Parker PL (1982) Sulfur uptake by salt grasses, mangroves, and seagrasses in anaerobic sediments. Geochim Cosmochim Acta 46:1121-1124

Goodman JL, Moore KA, Dennison WC (1995) Photosynthetic responses of eelgrass (Zostera marina L.) to light and sediment sulfide in a shallow barrier island lagoon. Aquat Bot 50:37-47

Gonzalez-Correa JM, Bayle JT, Sanchez-Lizasa JL, Valle C, Sanchez-Jerez P, Ruiz JM (2005) Recovery of deep Posidonia oceanica meadows degraded by trawling. J Exp Mar Biol Ecol 320:65-76

Greve TM, Borum J, Pedersen O (2003) Meristematic oxygen variability in eelgrass (Zostera marina). Limnol Oceanogr 48:210-216

Hemminga M, Duarte CM (2000) Seagrass Ecology. Cambridge University Press, Cambridge

Holmer M, Frederiksen MS (2007) Stimulation of sulfate reduction rates in Mediterranean fish farm sediments. Biogeochemistry 85:169-184

Holmer M, Kristensen E (1992) Impact of marine fish cage farming on metabolism and sulfate reduction of underlying sediments. Mar Ecol Prog Ser 80:191-201

Holmer M, Frederiksen MS, Møllegaard H (2005) Sulfur accumulation in eelgrass (Zostera marina) and effect of sulfur on eelgrass growth. Aquat Bot 81:367-379

Holmer M, Marba N, Diaz-Almela E, Duarte CM, Tsapakis M, Danovaro R (2007) Sedimentation of organic matter from fish farms in oligotrophic Mediterranean assessed through bulk and stable isotope $\left(\delta^{13} \mathrm{C}\right.$ and $\left.\delta^{15} \mathrm{~N}\right)$ analyses. Aquaculture 262:268-280

Jensen SI, Kühl M, Glud RN, Jørgensen LB, Priemé A (2005) Oxic microzones and radial oxygen loss from roots of Zostera marina. Mar Ecol Prog Ser 293:49-58

Jørgensen BB (1978) Comparison of methods for the quantification of bacterial sulfate reduction in coastal marine sediments. 2. Calculation from mathematical-models. Geomicrobiol J 1:29-47

Jørgensen BB (1979) A theoretical model of the stable sulfur isotope distribution in marine-sediments. Geochim Cosmochim Acta 43:363-374

Jørgensen BB, Bak F (1991) Pathways and microbiology of thiosulfate transformations and sulfate reduction in a marine sediment (Kattegat, Denmark). Appl Environ 
Microbiol 57:847-856

Kaplan IR, Emery KO, Rittenberg SC (1963) The distribution and isotopic abundance of sulphur in recent marine sediments off Southern California. Geochim Cosmochim Acta 27:297-331

Koch MS, Erskine JM (2001) Sulfide as a phytotoxin to the tropical seagrass Thalassia testudinum: interactions with light, salinity and temperature. J Exp Mar Biol Ecol 266: 81-95

Kristensen E, Andersen FØ (1987) Determination of organic carbon in marine sediments: a comparison of 2 CHNanalyzer methods. J Exp Mar Biol Ecol 109:15-23

Marba N, Duarte CM, Diaz-Almela E, Terrados J and 5 others (2005) Direct evidence of imbalanced seagrass (Posidonia oceanica) shoot population dynamics in the Spanish Mediterranean. Estuaries 28:53-62

Marba N, Santiago R, Díaz-Almela E, Álvarez E, Duarte CM (2006) Seagrass (Posidonia oceanica) vertical growth as an early indicator of fish farm-derived stress. Estuar Coast Shelf Sci 67:475-483.

Pasqualini V, Pergent-Martini C, Clabaut P, Pergent G (1998) Mapping of Posidonia oceanica using aerial photographs and side scan sonar: application off the Island of Corsica (France). Estuar Coast Shelf Sci 47:359-367

Pedersen O, Binzer T, Borum J (2004) Sulphide intrusion in eelgrass (Zostera marina L.). Plant Cell Environ 27: 595-602

Pérez M, Invers O, Ruiz JM, Frederiksen MS, Holmer M (2007) Physiological responses of the seagrass Posidonia oceanica to elevated organic matter content in sediments: an experimental assessment. J Exp Mar Biol Ecol 344(2): 149-160

Pregnall AM, Smith RD, Kursar TA, Alberte RS (1984) Metabolic adaptation of Zostera-marina (Eelgrass) to diurnal periods of root anoxia. Mar Biol 83:141-147

Raven JA, Scrimgeour CM (1997) The influence of anoxia on plants of saline habitats with special reference to the sulphur cycle. Ann Bot 79:79-86

Editorial responsibility: Howard Browman (Associate Editorin-Chief), Storebø, Norway
Rees CE, Jenkins WJ, Monster J (1978) Sulfur isotopic composition of ocean water sulfate. Geochim Cosmochim Acta 42:377-381

Rennenberg H (1984) The fate of excess sulfur in higherplants. Ann Rev Plant Physiol Plant Mol Biol 35:121-153

Roberts DG, McComb AJ, Kuo J (1984) The structure and continuity of the lacunar system of the seagrass Halophila ovalis (R-BR) Hook-F (Hydrocharitaceae). Aquat Bot 18: 377-388

Ruiz JM, Perez M, Romero J (2001) Effects of fish farm loadings on seagrass (Posidonia oceanica) distribution, growth and photosynthesis. Mar Pollut Bull 42:749-760

Sara G, Scipoliti D, Mazzola A, Modica A (2004) Effects of fish fanning waste to sedimentary and particulate organic matter in a southern Mediterranean area (Gulf of Castellammare, Sicily): a multiple stable isotope study $\left(\delta^{13} \mathrm{C}\right.$ and $\left.\delta^{15} \mathrm{~N}\right)$. Aquaculture 234(1-4):199-213

Smith RD, Pregnall AM, Alberte RS (1988) Effects of anaerobiosis on root metabolism of Zostera marina (eelgrass) implications for survival in reducing sediments. Mar Biol 98:131-141

Strauss H (1997) The isotopic composition of sedimentary sulfur through time. Palaeogeogr Palaeoclimatol Palaeoecol 132:97-118

Terrados J, Duarte CM, Kamp-Nielsen L, Agawin NSR and 6 others (1999) Are seagrass growth and survival constrained by the reducing conditions of the sediment? Aquat Bot 65:175-197

Trust BA, Fry B (1992) Stable sulfur isotopes in plants-a review. Plant Cell Environ 15:1105-1110

UNEP (2002) Vital water graphics - an overview of the state of the world's fresh and marine waters. United Nations Environment Programme, Nairobi

Zopfi J, Kjærr T, Nielsen LP, Jørgensen BB (2001) Ecology of Thioploca spp.: nitrate and sulfur storage in relation to chemical microgradients and influence of Thioploca spp. on the sedimentary nitrogen cycle. Appl Environ Microbiol 67:5530-5537

Submitted: September 19, 2006; Accepted: March 19, 2007 Proofs received from author(s): August 21, 2007 